\title{
Long-term effects of moderate elevation of oxidation- reduction potential on European seabass (Dicentrarchus labrax) in recirculating aquaculture systems
}

\author{
Li Xian ${ }^{1}$, Przybyla Cyrille ${ }^{2}$, Triplet Sebastien ${ }^{2}$, Liu Ying ${ }^{1, *}$, Blancheton Jean-Paul ${ }^{2,3,{ }^{*}}$ \\ ${ }^{1}$ Institute of Oceanology, Chinese Academy of Sciences, Qingdao 266071, China \\ 2 Ifremer, Palavas-les-Flots 34250, France \\ ${ }^{3}$ UMR Ecosym, USTL, Montpellier 34000, France \\ * Corresponding authors : Ying Liu, Tel.: +86 82898646; fax: +86 8 2898646; email address : \\ yinliu@qdio.ac.cn \\ Jean-Paul Blancheton, Tel.: +33 46713 0412; fax: +33 467130458 ; email address : \\ Jean.Paul.Blancheton@ifremer.fr
}

\begin{abstract}
:
The long term effects of moderate elevation ORP (oxidation-reduction potential) around 300-320 mV on the growth, hematological parameters and the ability of European seabass (Dicentrarchus labrax) to react against bacterial infection was studied in recirculating aquaculture systems (RASs). Two RASs, one with a moderate ozonation (RAS-O3) and a control (RAS-C) were used in this experiment. After 60 days, seabass reared in the RAS-O3 were more able to react against a Vibrio anguillarum infection. It was in spite of the fact that seabass in the RAS-O3 showed decreased feed intake, feed conversion rate, growth rate and modified hematological parameters compared with the fish in RAS-C. It is obvious that an ORP level of $300-320 \mathrm{mV}$ is too high for seabass to adapt in terms of the growth performance and the hematological parameters. However the increased ORP resulted in a better ability of the fish to react against bacterial infection. Our results strongly suggest that ORP for seabass in RAS should be elevated but not exceeding $300 \mathrm{mV}$ and a slightly increased and well controlled ORP level (above 240$270 \mathrm{mV}$ ) has a positive effect on the disease resistance of fish. For the future, molecular methods could be utilized to identify which functional groups of microbe are contributing to the ORP effect and investigate how ORP influenced fish physiology in RASs.
\end{abstract}




\section{Highlights}

- Long term impact of moderate elevation ORP levels on seabass in RAS. A 300-320 mV ORP level was stressful for seabass considering hematological parameters. A 300-320 mV ORP level resulted in lower feed intake and slower growth rate but a better resistance toward the bacterial infection. A slightly increased ORP level, kept under $300 \mathrm{mV}$, is recommended for seabass rearing in RAS.

Keywords : Oxidation-reduction potential, Seawater, European seabass, Welfare, RASs 


\section{Introduction}

In many countries, traditional aquaculture is being challenged by decreasing availability of suitable coastal areas, deteriorating quality of ground water, and an increasing demand for protein and lipids for food (Piedrahita, 2003). Consequently, as an alternative to traditional flow-through systems, recirculating aquaculture systems (RASs) that require a minimal supply of water, while providing a stable environment for the fish, will be important for the future of aquaculture. Rapid developments are occurring in the design of RASs and, in recent years, they have been encouraged in many European countries and China (Badiola et al., 2012; Xu et al., 2009).

Together with developments in RAS technology, there is now greater focus on fish welfare. In some countries, strict policies relating to the health and welfare of exported seafood regulate aspects of the operation of aquaculture processes, such as transport, handling and water quality (Huntingford et al., 2006). Consequently, optimization of RAS technology to promote fish welfare has been emphasized. Although many studies have been carried out to investigate important water quality parameters in RAS including $\mathrm{pH}, \mathrm{CO}_{2}$, and $\mathrm{O}_{2}$, there is currently limited information on the effects of oxidation-reduction potential (ORP) in RASs (Ashley, 2007).

The ORP of a system results from all reactions involving oxidations and reductions in the system and varies as a function of the standard potential, ion concentrations, temperature, and the number of electrons transferred (Banhidi, 2001). Typically, ozone is applied to seawater systems to control bacterial populations. Ozone injection in seawater has three main effects: Firstly, it improves water quality to promote fish welfare by reacting with toxic reductants, such as ammonia, and by disinfecting the seawater (Gonçalves and Gagnon, 2011); Secondly, ozone forms stable ozone-produced oxidants (OPO), expressed as total residual oxidants (TRO). They may, potentially lead to oxidative damage to fish tissues, including red blood cells and gill lamellar epithelium, and to modified hematocrit and reduced sodium and chloride levels (Fukunaga et al., 1992; Fukunaga et al., 1999; Jones et al., 2006). Third, elevation of the ORP 
may modify the whole microbe community, which may further affect fish performance (Attramadal et al., 2012). It is crucial to balance these effects and to find the level of ORP (ozone dose) that promotes fish welfare. Park et al.(2013) suggested that application of ozone at $20 \mathrm{~g} \mathrm{O}_{3} \mathrm{~kg}^{-1}$ feed day ${ }^{-1}$ in a seawater RAS is sufficient to improve the water quality without adversely affecting the growth of black seabream (Acanthopagrus schlegelii). However, there is no overall consensus as to the optimal ORP in seawater RASs. Practical information on the effect of ORP on fish performance in seawater RASs is necessary for their future design and operation. Moderate ozonation to an ORP of about 300-350 mV has been considered safe for marine fish in an RAS, although undesirable production of small quantities of bromate has been observed (Tango and Gagnon, 2003). In our previous research, 300-320 mv was speculated to be the optimal ORP, excluding fatal influence of TRO (Li et al., 2014).

In the present study we investigated the long-term effects of an ORP of around 300-320 mV on growth, hematological parameters, and resistance to bacterial infection of European seabass (Dicentrarchus labrax). The study aims to establish the optimal ORP level in RAS in order to inform improvements in their operation and technology.

\section{Materials and methods}

\subsection{Recirculating aquaculture systems and ORP control}

Two RASs, each consisting of three tanks, were located at Ifremer (Palavas les Flots Station, Montpellier, France). The experimental system, in which ORP was elevated by ozone injection into a skimmer, was called RAS- $\mathrm{O}_{3}$. The control system was referred to as RAS-C. Details of the construction of the systems and of the ORP controllers were reported in Li et al. (2014). During the whole experimental period of 90 days, the ORP level of the fish tanks in RAS- $\mathrm{O}_{3}$ was maintained between 300-320 mV. The ORP level of RAS-C was kept in the range 240-270 mV. Four ODEON devices (Ponsel, France) were used to monitor the ORP levels and other water quality parameters, including $\mathrm{pH}$, oxygen concentration, and temperature in the fish tanks of both RAS-C and RAS- $\mathrm{O}_{3}$.

In both systems, the oxygen concentration was adjusted daily to around $110 \%$ saturation at the outlets of the fish tanks, temperature was maintained at $21^{\circ} \mathrm{C}$, and $\mathrm{pH}$ was maintained at about 7.8 at the outlets by injecting sodium hydroxide into the pump tank . 


\subsection{Fish acclimation, stocking density and distribution}

European seabass were reared at the Ifremer station. Three months before the trial, they were transferred to the RASs. During the acclimation period, they were fed at $1.0-1.5 \%$ of their biomass per day.

After the acclimation period, fish were starved for $24 \mathrm{~h}$ and anesthetized using eugenol (40 mg $\mathrm{L}^{-1}$ ) (Filiciotto et al., 2012). Seabass of uniform size (about $250 \mathrm{~g}$ ) were weighed and randomly distributed to RAS-C and RAS-O $\mathrm{O}_{3}$ at an initial density of $25 \pm 0.04 \mathrm{~kg} \mathrm{~m}^{-3}$.

2.3. Measured parameters

\subsubsection{Water quality}

Water samples were collected from the outlet of the fish tanks three times per week for the measurement of TSS (total suspend solids), TAN (total ammonia nitrogen), $\mathrm{NO}_{2}-\mathrm{N}$ (nitrite-nitrogen) and $\mathrm{PO}_{4}-\mathrm{P}$ (orthophosphates). The TRO of the fish tanks in $\mathrm{RAS}-\mathrm{O}_{3}$ was measured daily. Details of the sampling process and measurements are described in Li et al. (2014): TAN, $\mathrm{NO}_{2}-\mathrm{N}$ and $\mathrm{PO}_{4}-\mathrm{P}$ were measured using an Alliance Futura instrument (Sociele AMS France, Frepillon, France). TRO was determined by colorimetric N,N-diethyl-p-phenylenediamine (DPD) method (Aqualytic, Langen, Germany).

\subsubsection{Feeding and growth}

Six 18-hour auto-feeder systems were utilized in RAS-C and RAS- $\mathrm{O}_{3}$. During the experiment, fish were fed Ep 3-5 dry pellets (Le Gouessant, Brittany, France). Each morning, feed was put into the feeder at a rate of $2 \%$ of the biomass of the fish and the quantity of uneaten feed in the feed trap was estimated on the following morning.

Growth parameters of the fish were calculated as follows:

Specific growth rate $\left(\mathrm{SGR} \% \mathrm{~d}^{-1}\right)=\left(\mathrm{Ln} \mathrm{W}_{\mathrm{f}}-\mathrm{Ln} \mathrm{W}_{\mathrm{i}}\right) \times 100 / \mathrm{n}$

Feed conversion ratio $(\mathrm{FCR})=\mathrm{F} /\left(\mathrm{B}_{\mathrm{f}}-\mathrm{B}_{\mathrm{i}}\right)$

Daily feed intake $\left(\right.$ DFI \%) $=(F / n) /\left(\left(B_{\mathrm{f}}+B_{i}\right) / 2\right) \times 100$

$W_{\mathrm{i}}$, and $W_{\mathrm{f}}$ are the initial and final mean body weights (g), respectively; $B_{f}$, and $B_{i}$ are the initial and final biomasses, respectively; $F$ is the total feed intake; $n$ is the duration of the experiment (days).

\subsubsection{Hematological parameters}


The fish were starved for $24 \mathrm{~h}$ before sampling. On the sampling day ( $61^{\text {th }}$ day), fish were removed from the tanks and blood was taken from the caudal vein with a syringe within $30 \mathrm{~s}$. One or two drops of blood were used immediately for measurements of hematological parameters including $\mathrm{pH}, \mathrm{pCO} 2, \mathrm{PO} 2, \mathrm{HCO}$, tCO2 (total $\left.\mathrm{CO}_{2}\right), \mathrm{sO} 2\left(\mathrm{O}_{2}\right.$ saturation), $\mathrm{Na}$ (sodium), K (potassium), iCa (ionized calcium), Glu (glucose), Hct (hematocrit) and Hb (hemoglobin) using an I-STAT portable analyzer (Abbott Laboratories, Abbott Park, IL, USA) equipped with CG8 ${ }^{+}$cartridges (Good et al., 2011; Li et al., 2014).

\subsection{Bacterial bath challenge}

Two independent RASs were prepared for the bacterial challenge and managed with the same rearing parameters (ozone-treated and control) (Person Le Ruyet et al., 2002; Volpatti et al., 2013). Each RAS was composed of three self-cleaning tanks $\left(1 \mathrm{~m}^{3}\right)$. The water treatment loop was composed of a 500-liter storage tank that collected the effluent, a UV-disinfection unit, a biofilter, a temperature controller, a sand filter, and a $\mathrm{CO}_{2}$ degassing column. The RAS overflow was treated by chlorination. Tanks were illuminated at 450 lux. The dissolved oxygen concentration was maintained at about $110 \%$ saturation at the tank outlet.

The V62 strain of Vibrio anguillarum was isolated from diseased European seabass reared in farms located along the French Mediterranean coast. After cultivation, the final concentration of $V$. anguillarum, evaluated using spectrophotometry $(630 \mathrm{~nm})$, was $10^{7}$ colony forming units $(\mathrm{CFU}) / \mathrm{ml}$. Four 100-liter baths, aerated with pure oxygen without water renewal, were prepared and $1000 \mathrm{ml}$ of the culture was introduced into each.

The bacterial bath challenge was carried out after the sampling and the biometric measurements. Twenty fish from each tank of the RAS-C and RAS- $\mathrm{O}_{3}$ (i.e., 60 fish from each RAS) were lightly anesthetized after $24 \mathrm{~h}$ of starvation. Each of the four baths received 30 tagged fish for 1 hour. After the challenge, the fish (ozone-treated or control) were placed in their respective RAS, as shown on Fig. 1. Mortalities in the fish tanks were recorded over the following week.

Fig 1

\subsection{Data analysis}


All data are expressed as means \pm S.D. Statistical analyses were performed using SPSS 16.0 for Windows. The data were first tested for the homogeneity using Levene's F-test. Percentage data were analyzed after arcsine transformation. Differences were considered statistically significant at $p<0.05$.

\section{Results}

\subsection{Water quality and ORP control}

During the experimental period, the ORP of RAS- $\mathrm{O}_{3}$ was maintained within the range 300-320 $\mathrm{mV}$. By adjusting the injection of pure $\mathrm{O}_{2}$, the oxygen saturations of RAS-C and RAS- $\mathrm{O}_{3}$ were maintained at about $110 \%$ at the outlets of the fish tanks to exclude the possibility of increased oxygen concentration being caused by the ozonation of RAS- $\mathrm{O}_{3}$.

There were no significant differences between RAS-C and RAS- $\mathrm{O}_{3}$ in any of the measured water parameters TAN, TSS, $\mathrm{NO}_{2}-\mathrm{N}$, and $\mathrm{PO}_{4}-\mathrm{P}$ (Table 1). The TRO of RAS- $\mathrm{O}_{3}$ was below the detection limit $\left(0.02 \mathrm{mg} \mathrm{L}^{-1}\right)$ during the whole period.

Table 1

\subsection{Feed intake and growth}

There were significant differences in the measured growth indices DFI, FCR, and SGR (Fig. 2). DFI and SGR were significantly higher in RAS-C than in RAS- $\mathrm{O}_{3}$. FCR of RAS-C was significantly lower than in RAS-O${ }_{3}$.

Fig 2

\subsection{Hematological parameters}

At the end of experiment, there were significant differences between RAS-C and RAS- $\mathrm{O}_{3}$ in the hematological parameters $\mathrm{pCO}_{2}, \mathrm{pO}_{2}, \mathrm{HCO}_{3}, \mathrm{sO}_{2}$, Glu, Hct and $\mathrm{Hb}$ (Table 2). Blood oxygen concentrations in RAS- $\mathrm{O}_{3}$ were significantly higher than in RAS-C, while blood $\mathrm{CO}_{2}$ concentrations in RAS- $\mathrm{O}_{3}$ were significantly lower than in RAS-C. K, Hct and Hb were significantly lower in RAS- $\mathrm{O}_{3}$ than in the RAS-C group. Glu of RAS- $\mathrm{O}_{3}$ was significantly 
higher than in RAS-C.

Table 2

\subsection{Bacterial batch challenge}

Cumulative mortalities of fish in RAS-C and RAS-O ${ }_{3}$ are shown in Fig 3. Mortality was clearly higher in RAS-C from the second day of the bacterial challenge. On the fourth day, the mortality of RAS-C fish was almost twice that of RAS- $\mathrm{O}_{3}$ fish. After the fourth day, mortalities in both RAS- $\mathrm{O}_{3}$ and RAS-C leveled off. At the end of the challenge period, $42 \%$ of fish were dead in RAS-C and $18 \%$ were dead in RAS- $\mathrm{O}_{3}$.

\section{Fig 3}

\section{Discussion}

In the current study, the ORP of RAS- $\mathrm{O}_{3}$ and the oxygen concentrations in both RAS-C and RAS- $\mathrm{O}_{3}$ were well controlled. More pure oxygen was injected into RAS-C than into RAS-O${ }_{3}$ to maintain similar oxygen concentrations. There were no significant differences in the measured nutrient parameters in the water, and the biomasses of fish used in this study were well below the maximum capacities of these RASs. However the water in RAS- $\mathrm{O}_{3}$ was clearer than in RAS-C (visual inspection) presumably because of the strong oxidative effect of ozone. A TRO of $0.06 \mathrm{mg} \mathrm{L}^{-1}$ was considered as the safety limit for turbot (Reiser et al., 2011). During the whole period of our experiment, the TRO of the fish tanks in $\mathrm{RAS}-\mathrm{O}_{3}$ did not exceed $0.02 \mathrm{mg}$ $\mathrm{L}^{-1}$, which is considered as safe (Saroglia and Scarano, 1983).

No dead fish were found during the whole period. The values of FCR, DFI and SGR in RAS-C were consistent with previous results in this facility, using the same density and environmental conditions. We observed that an ORP of 300-320 mV negatively affected the feed intake, feed conversion rate, and growth rate of the fish. Fish in RAS- $\mathrm{O}_{3}$ took in less feed and had slower growth rates than those in RAS-C. We infer that an ORP 300-320 $\mathrm{mV}$ is unsuitable for seabass in terms of the growth performance. 
The analysis of hematological parameters revealed statistically significant differences between RAS-C and RAS- $\mathrm{O}_{3}$ but their values were within published expected ranges for seabass (Sammouth et al. 2009). Lower $\mathrm{Hb}$ and Hct and altered blood-gas balance (higher $\mathrm{O}_{2}$ and lower $\mathrm{CO}_{2}$ ), were measured in the RAS- $\mathrm{O}_{3}$ fish compared with values in RAS-C. These observations were in accordance with our previous study ( $\mathrm{Li}$ et al., 2014). The lower hemoglobin concentration in RAS- $\mathrm{O}_{3}$ indicates either inhibition of hemoglobin synthesis or increased destruction of $\mathrm{Hb}$. Possibly fish in RAS- $\mathrm{O}_{3}$ consumed insufficient food quantity, resulting in anemia and lowered hemoglobin levels (Hansen et al., 2007). Fukunaga et al. (1991; 1999) showed that a short-term overdose of ozone induced lipid peroxidation of the red cell membranes and hemolysis. However, it is unclear whether long-term TRO values below 0.02 $\mathrm{mg} \mathrm{L}^{-1}$ in fish tanks would destroy red blood cells or lower Hb concentration and Hct. The function of hemoglobin is to transport $\mathrm{O}_{2}$ and $\mathrm{CO}_{2}$ in the blood. However, the blood oxygen concentration of fish in RAS- $\mathrm{O}_{3}$ was significantly higher, and blood carbon dioxide significantly lower, than in RAS-C. Thus, it is unclear how an increase in ORP could increase blood $\mathrm{O}_{2}$ and decrease $\mathrm{CO}_{2}$ concentration. Possibly, the increased ORP elevated the Hb- $\mathrm{O}_{2}$ affinity through changes in ions such as potassium, resulting in the enhanced oxygen transport and altered blood-gas balance.

Most of a living organism's energy is derived from carbohydrate transformation, which increases to meet the energy demands of stressful situations. The blood glucose level is a well-known biomarker for stress in fish (Endo et al., 2006). Fish in RAS-O $\mathrm{O}_{3}$ had higher blood glucose concentrations, which is in accordance with our previous studies (Li et al., 2014). Therefore, our analysis of hematological parameters suggests that seabass are unable to adapt to an ORP of 300-320 mV. Further investigation of ORP in relation to hematological parameters of fish is necessary.

Interestingly, the mortality in RAS- $\mathrm{O}_{3}$ after the bacterial challenge was half that in RAS-C, despite the lower feed intake and growth rate in RAS- $\mathrm{O}_{3}$. The ability of fish to combat bacterial infections depends upon their immune status, the integrity of the skin, and microbial defenses on the body surface and in the gut. The compositions of the bacterial communities of fish are related to the bacterial population in their aquatic habitat (Cahill, 1990; Horsley, 1973). In a 
RAS, the microflora of fish is strongly influenced by the bacterial populations of the system, especially in the biofilter (Kruse et al., 2013; Leonard et al., 2000). In fact, there are several bacteria in fish that inhibit V. anguillarum (Olsson et al., 1992). The gastrointestinal tract is host to bacteria that constitute a barrier against pathogens; $60 \%$ of these protective bacteria inhibit exogenous pathogenic bacteria and 28\% specifically inhibit $V$. anguillarum (Westerdahl, 1991). It is possible that the elevated ORP in RAS- $\mathrm{O}_{3}$ selected a specific microflora community in the system and in the fish that enhanced the resistance of seabass to $V$. anguillarum infection. Attramadal et al. (2012) showed that moderately ozonated RASs had more mature and stable microbial communities than non-ozonated systems. However, limited information is available on the direct effects of ozonation on the microbial environment or on the performance of marine fish after ozonation. Further knowledge of the functional and taxonomic groups of bacteria associated with the water and the fish in RASs in relation to elevated ORP would help understanding of the related mechanisms.

In conclusion, the results of the current research indicated that ORP around 300-320 $\mathrm{mV}$ in fish tank had a negative influence on the feed intake, feed conversion rate and growth rate. Meanwhile considering hematological parameters, it appears as impossible for seabass to adapt to ORP of $300-320 \mathrm{mV}$. However fish under $300-320 \mathrm{mV}$ were less sensible to bacterial infection, which suggests that a slightly increased and well controlled ORP level (above 240 $270 \mathrm{mV}$ ) has a positive effect. Consequently, we suggest that ORP for seabass in RAS should be elevated but not exceed $300 \mathrm{mV}$. A slight increase of the ORP level in RAS seems to improve the water quality and the ability of the fish to react against pathogenic bacteria. Moreover a strict control of the TRO level is strongly suggested and further studies are necessary to identify how ORP alters the physiological fish parameters and microbe community in both water and fish.

\section{Acknowledgements}

The authors are grateful to our many colleagues in Ifremer Palavas station, who have contributed to our study. This work was supported by the National Nature Science Founds (grant no. 41306152).

This article is also a part of cooperation between China (IOCAS), France (Ifremer) and Italy 
(University of Messina).

\section{References}

Ashley, P.J., 2007. Fish welfare: Current issues in aquaculture. Appl. Anim. Behav., Sci. 104, 199-235.

Attramadal, K.J.K., Øie, G., Størseth, T.R., Alver, M.O., Vadstein, O., Olsen, Y., 2012. The effects of moderate ozonation or high intensity UV-irradiation on the microbial environment in RAS for marine larvae. Aquaculture 330-333, 121-129.

Badiola, M., Mendiola, D., Bostock, J., 2012. Recirculating Aquaculture Systems (RAS) analysis: Main issues on management and future challenges. Aquac. Eng., 51, 26-35.

Banhidi, M., 2001. pH and ORP. Metal Finishing 99, 593-599.

Cahill, M., 1990. Bacterial flora of fishes: A review. Microb. Ecol., 19, 21-41.

Endo, H., Yonemori, Y., Musiya, K., Maita, M., Shibuya, T., Ren, H., Hayashi, T., Mitsubayashi, K., 2006. A needle-type optical enzyme sensor system for determining glucose levels in fish blood. Anal. chim. acta., 573, 117-124.

Filiciotto, F., Buscaino, G., Buffa, G., Bellante, A., Maccarrone, V., Mazzola, S., 2012. Anaesthetic Qualities of Eugenol and 2-Phenoxyethanol and Their Effect on Same Haematological Parameters in Farmed European Sea Bass (Dicentrarchus labrax L.). J. Anim. Vet. Adv., 11, 494-502.

Fukunaga, K., Nakazono, N., Suzuki, T., Takama, K., 1999. Mechanism of oxidative damage to fish red blood cells by ozone. IUBMB Life 48, 631-634.

Fukunaga, K., Suzuki, T., Arita, M., Suzuki, S., Hara, A., Yamauchi, K., Shinriki, N., Ishizaki, K., Takama, K., 1992. Acute toxicity of ozone against morphology of gill and erythrocytes of Janpanese charr (Salvelinus leucomaenis). Comp. Biochem. Physiol. C: Pharmacol. Toxicol. Endocrinol., 101, 331-336.

Fukunaga, K., Suzuki, T., Takama, K., 1991. Effect of ozone exposure on the compositions of gill and erythrocyte membrane lipids and proteins of Japanese charr (Salvelinus leucomaenis). Comp. Biochem. Physiol. B: Biochem. Mol. Biol., 100, 481-487.

Gonçalves, A.A., Gagnon, G.A., 2011. Ozone Application in Recirculating Aquaculture System: An Overview. Ozone: Science \& Engineering 33, 345-367. 
Good, C., Davidson, J., Welsh, C., Snekvik, K., Summerfelt, S., 2011. The effects of ozonation on performance, health and welfare of rainbow trout (Oncorhynchus mykiss) in low-exchange water recirculation aquaculture systems. Aquac. Eng., 44, 97-102

Hansen, A.-C., Rosenlund, G., Karlsen, Ø., Koppe, W., Hemre, G.-I., 2007. Total replacement of fish meal with plant proteins in diets for Atlantic cod (Gadus morhua L.) I-Effects on growth and protein retention. Aquaculture 272, 599-611.

Horsley, R.W., 1973. The Bacterial Flora of the Atlantic Salmon (Salmo salar L.) in Relation to its Environment. J. Appl. Bacteriol., 36, 377-386.

Huntingford, F.A., Adams, C., Braithwaite, V.A., Kadri, S., Pottinger, T.G., Sandoe, P., Turnbull, J.F., 2006. Current issues in fish welfare. J. Fish Biol., 68, 332-372.

Jones, A.C., Gensemer, R.W., Stubblefield, W.A., van Genderen, E., Dethloff, G.M., Cooper, W.J., 2006. Toxicity of ozonated seawater to marine organisms. Environ. Toxicol. Chem., 25, 2683-2691.

Kruse, M., Keuter, S., Bakker, E., Spieck, E., Eggers, T., Lipski, A., 2013. Relevance and Diversity of Nitrospira Populations in Biofilters of Brackish RAS. PloS one 8, e64737.

Leonard, N., Blancheton, J.P., Guiraud, J.P., 2000. Populations of heterotrophic bacteria in an experimental recirculating aquaculture system. Aquac. Eng., 22, 109-120.

Li, X., Blancheton, J.-P., Liu, Y., Triplet, S., Michaud, L., 2014. Effect of oxidation-reduction potential on performance of European sea bass (Dicentrarchus labrax) in recirculating aquaculture systems. Aquacult. Int., 22, 1263-1282..

Saroglia, M.G., Scarano, G., 1983. Risk from residual chlorine in cooling waters used for aquacultural purposes , in: Jolley, R.L., Brungs W.A., Cotruvo, J.A., Cumming, R.b., Mattice, J.S., Jacobs, V.A. (Eds.), Water chlorination, environmental impact and health effects, volume 4 book 2 Environmental, Health, and Risk. Ann Arbor Science, John Wiley \& Sons Ltd, Michigan, pp. 1437-1445.

Olsson, J.C., Westerdahl, A., Conway, P.L., Kjelleberg, S., 1992. Intestinal colonization potential of turbot (Scophthalmus maximus) and dab (Limanda limanda) associated bacteria with inhibitory effects against Vibrio anguillarum. Appl. Environ. Microbiol., 58, 551-556.

Park, J., Kim, P.K., Lim, T., Daniels, H.V., 2013. Ozonation in seawater recirculating systems for black seabream Acanthopagrus schlegelii (Bleeker): Effects on solids, bacteria, water clarity, and color. Aquac. Eng., 55, 1-8.

Person-Le Ruyet, J., Pichavant, K., Vacher, C., Le Bayon, N., Severe, A., Boeuf, G., 2002. 
Effects of $\mathrm{O} 2$ supersaturation on metabolism and growth in juvenile turbot (Scophthalmus maximus L.). Aquaculture 205, 373-383.

Piedrahita, R.H., 2003. Reducing the potential environmental impact of tank aquaculture effluents through intensification and recirculation. Aquaculture 226, 35-44.

Reiser, S., Wuertz, S., Schroeder, J.P., Kloas, W., Hanel, R., 2011. Risks of seawater ozonation in recirculation aquaculture - Effects of oxidative stress on animal welfare of juvenile turbot (Psetta maxima, L.). Aquat. Toxicol., 105, 508-517.

Sammouth, S., d’Orbcastel, E.R., Gasset, E., Lemarie, G., Breuil, G., Marino, G., Coeurdacier, J.L., Fivelstad, S., Blancheton J.P., 2009. The effect of density on sea bass (Dicentrarchus labrax) performance in a tank-based recirculating system. Aquac. Eng., 40, 72-78.

Tango, M.S., Gagnon, G.A., 2003. Impact of ozonation on water quality in marine recirculation systems. Aquac. Eng., 29, 125-137.

Volpatti, D., Bulfon, C., Tulli, F., Galeotti, M., 2013. Growth parameters, innate immune response and resistance to Listonella (Vibrio) anguillarum of Dicentrarchus labrax fed carvacrol supplemented diets. Aquac. Res., 45, 31-44.

Westerdahl, A., Olsson, J.C., Kjelleberg, S., Conway, P.L.,1991. Isolation and characterization of turbot (Scophtalmus maximus)-associated bacteria with inhibitory effects against Vibrio anguillarum. Appl Environ Microbiol, 57, 2223-2228.

Xu, J., Xu, H., Ni, Q., Liu, H., 2009. The development of recirculating aquaculture systems in China. Fish., Moder. 1-7. (written in Chinese with English abstract) 
Table 1 : Water quality (mg $L-1)$ in the outlet of fish tanks of RAS-C and RAS-O3.

\begin{tabular}{|l|l|l|}
\hline Parameters & RAS-C & $\mathrm{RAS}_{3} \mathrm{O}_{3}$ \\
\hline TSS & $7.28 \pm 2.34$ & $6.91 \pm 3.15$ \\
\hline TAN & $0.73 \pm 0.21$ & $0.71 \pm 0.22$ \\
\hline $\mathrm{NO}_{2}-\mathrm{N}$ & $0.05 \pm 0.01$ & $0.05 \pm 0.01$ \\
\hline $\mathrm{PO}_{4}-\mathrm{P}$ & $0.95 \pm 0.21$ & $0.89 \pm 0.11$ \\
\hline TRO & - & - \\
\hline
\end{tabular}

-, Lower than detectable limits $\left(0.02 \mathrm{mg} \mathrm{L}^{-1}\right)$.

Table 2 : Hematological parameters of fish in RAS-C and RAS-O3 at the end of experiment.

\begin{tabular}{|c|c|c|c|}
\hline Parameters & RAS-C & RAS- $\mathrm{O}_{3}$ & $p$ \\
\hline $\mathrm{pH}$ & $7.28 \pm 0.06$ & $7.31 \pm 0.06$ & 0.31 \\
\hline$p \mathrm{CO}_{2}\left(\mathrm{mmol} \mathrm{L}^{-1}\right)$ & $18.18 \pm 2.27$ & $13.90 \pm 1.94$ & 0 \\
\hline $\mathrm{pO}_{2}(\mathrm{~mm} \mathrm{Hg})$ & $40.75 \pm 4.52$ & $59.42 \pm 6.72$ & 0 \\
\hline $\mathrm{HCO}_{3}\left(\mathrm{mmol} \mathrm{L}^{-1}\right)$ & $8.53 \pm 0.34$ & $6.92 \pm 0.31$ & 0 \\
\hline $\mathrm{tCO}_{2}\left(\mathrm{mmol} \mathrm{L}^{-1}\right)$ & $9.00 \pm 0.85$ & $7.33 \pm 0.78$ & 0 \\
\hline $\mathrm{sO}_{2}(\%)$ & $62.25 \pm 16.41$ & $88.25 \pm 3.86$ & 0 \\
\hline $\mathrm{Na}\left(\mathrm{mmol} \mathrm{L}^{-1}\right)$ & $159.42 \pm 2.07$ & $158.92 \pm 2.97$ & 0.64 \\
\hline $\mathrm{K}\left(\mathrm{mmol} \mathrm{L}^{-1}\right)$ & $4.00 \pm 0.46$ & $3.41 \pm 0.17$ & 0 \\
\hline$i \mathrm{Ca}\left(\mathrm{mmol} \mathrm{L}^{-1}\right)$ & $1.48 \pm 0.04$ & $1.52 \pm 0.07$ & 0.11 \\
\hline Glu (mg dL ${ }^{-1}$ ) & $82.17 \pm 7.08$ & $88.42 \pm 9.14$ & 0.04 \\
\hline Hct (\%PCV) & $25.00 \pm 3.22$ & $16.91 \pm 3.17$ & 0 \\
\hline $\mathrm{Hb}\left(\mathrm{g} \mathrm{dL}^{-1}\right)$ & $9.12 \pm 0.85$ & $5.65 \pm 1.13$ & 0 \\
\hline
\end{tabular}

When $p<0.05$, difference is significant. 
Figure 1 : The distribution of fish in the bacterial challenge.

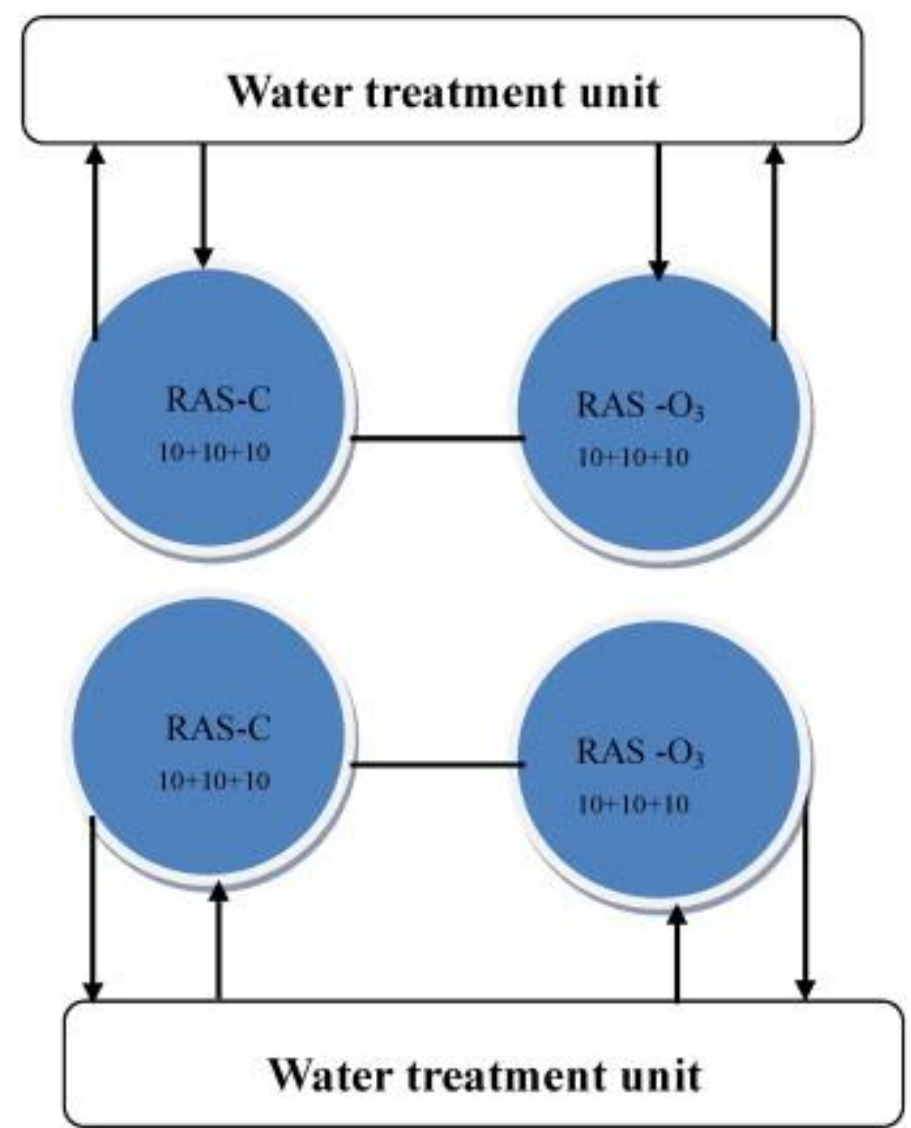


Figure 2 : Growth indexes of fish in RAS-C and RAS-O3 at the end of the experiment ${ }^{*}$ Significant difference $(p<0.05))$.
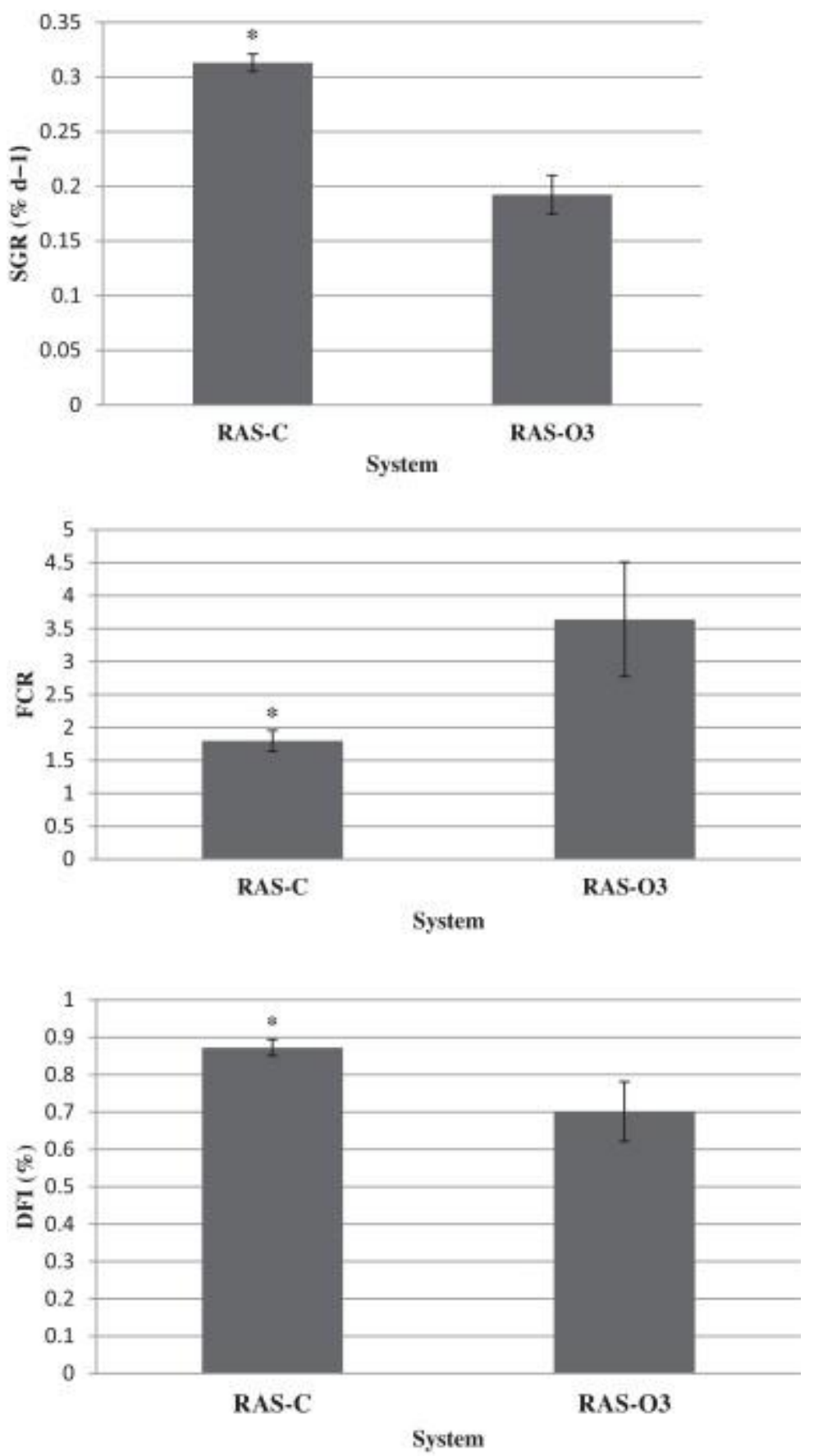
Figure 3 : Cumulative fish mortalities of both RAS-O3 and RAS-C during the bacterial challenge.

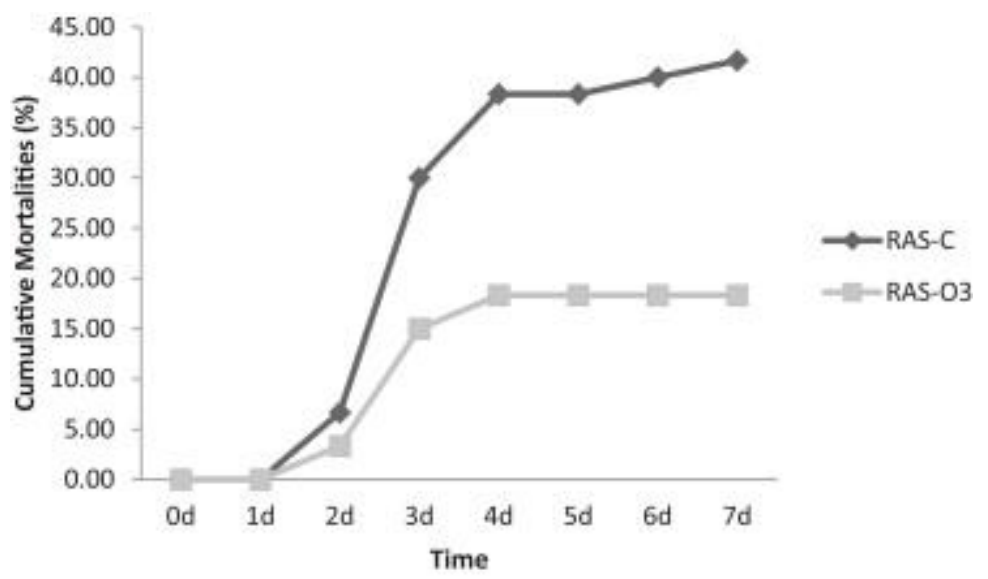

